\title{
SISTEM KEUANGAN ISLAM: SEBUAH TELAAH TEORITIS
}

\author{
Muh. Arafah, M.E \\ Dosen Tetap IAIN Bone \\ rafhli@yahoo.com
}

\begin{abstract}
Abstrak
Sistem Keuangan Islam merupakan embrio kekuatan ekonomi di negara ini, di zamannya ia mampu menjadi sistem yang bisa mensejahterakan umatnya. Di masa krisis, ia mampu lolos dari kebangkrutan, sekalipun tidak mendapat bantuan dana BLBI. Konsep yang mengandung ke-Islaman ini harus menjadi kekuatan baru dalam membangkitkan kembali perekonomian negeri ini. Sistem Keuangan Islam ini berkembang pesat memainkan peranan penting dalam mengalokasikan sumber daya dan meningkatkan pembangunan ekonomi.
\end{abstract}

Kata Kunci: Sistem Keuangan Islam, karakteristik, instrument, strategi

\section{PENDAHULUAN}

Sistem keuangan global yang berlaku saat ini sebagian besar menganut sistem ekonomi berbasis bunga. Dalam ruang lingkup domestik masing-masing negara, sistem keuangan menitikberatkan pada kebijakan ekonomi menuju keseimbangan menggunakan instrumen bunga, sehingga bunga menjadi variabel vital dalam penyusunan kebijakan ekonomi baik moneter maupun fiskal. Pada ruang lingkup global, perekonomian berbasis bunga membentuk corak interaksi keuangan menjadi khas. Dari perspektif analisis kritis, bunga membuat sistem keuangan global menjadi pincang, dimana negara-negara miskin dan berkembang harus terus tergantung secara financial kepada negara maju. Sifat predetermined return bunga akan membuat perilaku para pemegang kapital cenderung menggunakan uangnya sebagai alat untuk mengenerate pendapatan melalui sektor financial dari pada mendapatkan keuntungan melalui aktivitas produktif di sektor riil. Kecenderungan ini pada tingkat negara semakin memperdalam kepincangan financial global. Negara-negara maju menjadi korban debt addicted, sementara negara-negara miskin dan berkembang tak pernah bisa bebas dari jeratan utang yang terus menggelembung (Nur Chamid, 2013).

Pada dasarnya sistem keuangan suatu negara sangat dipengaruhi oleh sistem ekonomi yang dianut. Sistem ekonomi menunjuk pada satu kesatuan mekanisme dan lembaga pengambilan keputusan yang mengimplementasikan keputusan tersebut terhadap produksi, konsumsi dan distribusi pendapatan. Karena itu, sistem ekonomi merupakan sesuatu yang penting bagi perekonomian suatu negara. Sistem ekonomi terbentuk karena berbagai faktor yang kompleks, misalnya ideologi dan sistem kepercayaan, pandangan hidup, lingkungan geografi, politik, sosial budaya, dan lain-lain (Nur Kholis, 2017).

Suatu sistem ekonomi mengandung 2 sektor, yakni sektor riil dan keuangan. Dalam perkembangannya, sektor keuangan dalam ekonomi Islam lebih cepat berkembang daripada sektor riilnya. Bahkan dalam empat puluh tahun terakhir, keuangan Islam telah bertumbuh dengan pesat dan saat in telah menjadi industri yang memiliki kontribusi penting dalam perekonomian nasional tidak hanya di negara-negara Muslim, namun juga di berbagai negara di seluruh dunia. Keuangan Islam telah membuat terobosan signifikan dalam lingkungan global dengan memfasilitasi diversifikasi resiko dan berkontribusi dalam stabilitas keuangan global. Kini keuangan Islam telah menjadi bagian integral dalam sistem keuangan internasional. Di beberapa negara, termasuk Indonesia, Malaysia dan lain-lain, sistem ekonominya menganut dual economic system, sistem keuangannya pun juga dual financial system (Nur Kholis, 2017). 
Selama beberapa dekade terakhir, perkembangan keuangan Islam menunjukkan perubahan dan dinamika dramatis yang cepat. Sebagai bagian instrumen pengembang aktivitas di bidang ekonomi, beragam tantangan dihadapi sistem keuangan Islam, seperti pada aspek teoritis, operasional dan implementasi (Zamir Iqbal dan Abbas Mirakhor, 2008). Pada aspek teoritis, dibutuhkan pengembangan prinsip, filosofis dan fungsi sistem keuangan atas dasar pembagian keuntungan dan kerugian (profit-loss sharing). Pada sisi operasional, dibutuhkan perhatian terhadap inovasi, intermediasi, disiplin dan pengendalian resiko, sementara pada sisi implementasi diperlukan aplikasi sistem yang harus disesuaikan dengan regulasi, dan kondisi perekonomian masyarakat saat ini. Bahkan, operasional perbankan Islam pada skala sistem yang efisien selama ini, amat dibatasi oleh distorsi dalam ekonomi, seperti kurangnya kerangka pengawasan yang kuat dan regulasi yang cermat dalam sistem keuangan (Zamir Iqbal dan Abbas Mirakhor, 2008). Hal ini dapat memberikan dampak pada ketidakseimbangan finansial dalam fiskal dan moneter, dan tidak memberikan efisiensi perkembangan perbankan Islam sehingga terjadilah disequilibrium financial.

\section{TINJAUAN PUSTAKA}

\section{A. Sistem keuangan}

Keuangan adalah senjata politik, sosial, dan ekonomi yang ampuh di dunia modern. Ia berperan penting tidak hanya dalam alokasi dan distribusi sumber daya yang langka, tetapi juga dalam stabilitas dan pertumbuhan ekonomi. Karena sumber-sumber lembaga keuangan berasal dari deposit yang diletakkan oleh bagian yang representative mewakili seluruh penduduk, cukup rasional kalau ia juga dianggap sebagai sumber nasional. Seluruhnya harus digunakan untuk kesejahteraan bagi masyarakat. Namun karena sumber-sumber keuangan itu sangat langka maka perlu digunakan dengan keadilan dan efesiensi yang optimal (M Umer Chapra, 1999).

Sistem keuangan adalah suatu aturan yang menjelaskan sumber-sumber dana keuangan bagi negara dalam proses alokasi dana tersebut bagi kehidupan masyarakat (Said Sa'ad Marthon, 2004). Peran utama sistem keuangan adalah mendorong alokasi efesiensi sumber daya keuangan dan sumber daya riil untuk berbagai tujuan dan sasaran yang beraneka ragam (Zamir Iqbal dan Abbas Mirakhor, 2008).

Sistem keuangan merupakan tatanan perekonomian dalam suatu negara yang berperan melakukan aktifitas jasa keuangan yang diselenggarakan oleh lembaga keuangan. Tugas utama sistem keuangan adalah sebagai mediator antara pemilik dana dengan pengguna dana yang digunakan untuk membeli barang atau jasa serta investasi. Oleh karena itu peranan sistem keuangan sangat vital dalam mendorong pertumbuhan ekonomi, serta mampu memprediksi perkembangan perekonomian dimasa yang akan datang (Andri Soemitra, 2010).

\section{B. Sistem keuangan Islam}

Keuangan Islam adalah sebuah sistem yang bersumber dari Al-Quran dan Sunnah, serta dari penafsiran para ulama terhadap sumber-sumber wahyu tersebut. Dalam berbagai bentuknya, struktur keuangan Islam telah menjadi sebuah peradaban yang tidak berubah selama empat belas abad. Selama tiga dasawarsa terakhir, struktur keuangan Islam telah tampil sebagai salah satu implementasi modern dari sistem hukum Islam yang paling penting dan berhasil, dan sebagai ujicoba bagi pembaruan dan perkembangan hukum Islam pada masa mendatang

Ciri-ciri sistem keuangan Islam adalah (Qutb Ibrahim, 2007):

1. Harta publik dalam sistem keuangan Negara Islam adalah harta Allah.

2. Rasul adalah orang pertama yang melakukan praktik keuangan Islam.

3. Al-Qur'an dan sunah merupakan sumber yang mendasar bagi keuangan Islam.

4. Sistem keuangan Islam adalah system keuangan yang universal. 
5. Keuangan khusus dalam Islam menopang sistem keuagan Negara Islam.

6. Sistem keuangan Islam mengambil prinsip alokasi terhadap layanan sebagai sumber sumber pendapatan Negara.

7. Sistem keuangan Islam ditandai dengan transparansi.

8. Sistem keuangan Negara Islam merupakan gerakan kebaikan

9. Sistem keuangan Islam adalah modal toleransi umat Islam.

Pengertian sistem keuangan Islam merupakan sistem keuangan yang menjembatani antara pihak yang membutuhkan dana dengan pihak yang kelebihan dana melalui produk dan jasa keuangan yang sesuai dengan prinsip-prinsip Islam.

Prinsip-prinsip Islam dalam sistem keuangan yaitu (Qutb Ibrahim, 2007):

1. Kebebasan bertransaksi, namun harus didasari dengan prinsip suka sama suka dan tidak ada yang dizalimi, dengan didasari dengan akad yang sah. Dan transaksi tidak boleh pada produk yang haram. Asas suka sama suka untuk melakukan kegiatan bisnis atau perniagaan sangat penting. Tidak ada unsur paksaan dalam hal ini yang dapat menimbulkan kerugian masing-masing.

2. Bebas dari maghrib (maysir yaitu judi atau spekulatif yang berfungsi mengurangi konflik dalam sistem keuangan, gharar yaitu penipuan atau ketidak jelasan, riba pengambilan tambahan dengan cara batil).

3. Bebas dari upaya mengendalikan, merekayasa dan memanipulasi harga.

4. Semua orang berhak mendapatkan informasi yang berimbang, memadai, akurat agar bebas dari ketidaktahuan bertransaksi.

5. Pihak-pihak yang bertransaksi harus mempertimbangkan kepentingan pihak ketiga yang mungkin dapat terganggu, oleh karenanya pihak ketiga diberikan hak atau pilihan.

Menurut Muhammad (Muhammad, 2000), Adapun prinsip-prinsip dalam keuangan

Islam adalah:

1. Larangan menerapkan bunga pada semua bentuk dan jenis transaksi

2. Menjalankan aktivitas bisnis dan perdagangan berdasarkan pada kewajaran dan keuntungan yang halal.

3. Mengeluarkan zakat dari hasil kegiatannya.

4. Larangan menjalankan monopoli.

5. Bekerja sama dalam membangun masyarakat, melalui aktivitas bisnis dan perdagangan yang tidak dilarang oleh Islam

Prinsip-prinsip hukum syariah mempunyai perbedaan dengan keuangan konvensional.

Perbedaan ini dapat dijadikan dasar praktik keuangan yang mestinya sesuai dengan syariah (Alam, 2011):

1. Larangan bunga (riba): Dalam bentuk keuangan konvensional dibuat penerimaan melalui bunga (riba) sedangkan dalam hukum Islam praktik riba tidak diperbolehkan.

2. Larangan ketidakpastian: Ketidakpastian dalam kontrak tidak diperbolehkan karena dapat menimbulkan spekulatif yang melibatkan gharar (ketidakpastian yang berlebihan).

3. Risiko profit and loss sharing: Pihak yang terlibat dalam transaksi keuangan herus berbagi risiko dan keuntungan antara pemberi pinjaman dan peminjam.

4. Etika investasi: Investasi di industri yang dilarang dalam al-Qur'an seperti alkhohol, perjudian dan babi tidak dianjurkan.

5. Aset riil: Setiap transaksi harus nyata dan dapat diidentifikasi. Utang tidak dapat dijual sehingga risiko terkait tidak dapat ditransfer kepada orang lain (Novita Anjarsari, 2013)

Tujuan utama sistem keuangan Islam adalah: menghapus bunga dari semua transaksi keuangan dan menjalankan aktifitasnya sesuai dengan prinsip-prinsip Islam, distribusi kekayaan yang adil dan merata, kemajuan pembangunan ekonomi (Mervyn K. Lewis Dan Latifa M. Algoud, 2007). 
Sistem keuangan Islam bertujuan untuk memberikan jasa keuangan yang halal kepada komunitas muslim, di samping itu juga diharapkan mampu memberikan kontribusi yang layak bagi tercapainya tujuan sosio-ekonomi Islam. Target utamanya adalah kesejahteraan ekonomi, perluasan kesempatan kerja, tingkat pertumbuhan ekonomi yang tinggi, keadilan sosio-ekonomi dan distribusi pendapatan, kekayaan yang wajar, stabilitas nilai uang, dan mobilisasi serta investasi tabungan untuk pembangunan ekonomi yang mampu memberikan jaminan keuntungan (bagi hasil) kepada semua pihak yang terlibat (M. Umer Chapra, 2000).

Sistem keuangan Islam diharapkan mampu menjadi alternatif terbaik dalam mencapai kesejahteraan masyarakat. Penghapusan prinsip bunga dalam sistem keuangan Islam memiliki dampak makro yang cukup signifikan, karena bukan hanya prinsip investasi langsung saja yang harus bebas dari bunga, namun prinsip investasi tak langsung juga harus bebas dari bunga. Perbankan sebagai lembaga keuangan utama dalam sistem keuangan dewasa ini tidak hanya berperan sebagai lembaga perantara keuangan (financial intermediary), namun juga sebagai industri penyedia jasa keuangan (financial industry) dan instrumen kebijakan moneter yang utama (Heri Sudarsono, 2003).

Mengapa ada keuangan Islami? Minimal ada 3 faktor yang melatarbelakangi lahirnya keuangan Islam, yaitu: relijius ideologis, empiris pragmatis, dan akademik idealis. Relijius ideologis merupakan latar belakang yang bersifat fundamental berkaitan dengan ajaran Islam, yaitu a). Keinginan umat Islam untuk mengaplikasikan konsep konsep keuangan Islami sebagai upaya menjadikan Islam sebagai way of life. b). Konsep dan praktek keuangan konvensional yang telah ada melanggar berbagai prinsip syariah, misalnya mengandung unsur riba, gharar, maysir. Sedangkan dari faktor empiris pragmatis politis, bahwa setelah masa kemerdekaan dari kolonialisme Barat (sekitar tahun 1940-an), di negara negara muslim muncul keinginan untuk juga merdeka secara ekonomi. Sistem keuangan konvensional yang ada dipandang lebih menguntungkan Barat dan merugikan negara-negara muslim yang umumnya tergolong negara berkembang (developing countries). Pada saat yang bersamaan, terdapat sejumlah besar dana milik muslim, terutama negara penghasil minyak, yang ingin dikelola secara Islami. Keinginan itu mewujud dalam bentuk di antaranya pendirian IDB (Islamic Development Bank). IDB didirikan di Jeddah sebagai hasil agreement menterimenteri OIC pada Desember 1973, dan mulai beroperasi pada tahun 1975. IDB bukan bank komersial, tetapi development bank (seperti World Bank) yang memiliki misi pemberdayaan pembangunan negara-negara muslim. Sedangkan dari sisi latar belakang akademik, ditemukan dari berbagai kajian akademik yang dilakukan bahwa sistem keuangan konvensional berpotensi untuk: a). menimbulkan instabilitas dan krisis ekonomi, b). memperlebar kesenjangan antara miskin dan kaya, c). ada alternatif sistem keuangan yang secara konseptual lebih mampu menciptakan sistem keuangan yang lebih adil dan harmoni (Nur Kholis, 2017).

\section{METODE PENELITIAN}

Jenis penelitian ini merupakan penelitian kepustakaan (library research), "penelitian perpustakaan bertujuan untuk mengumpulkan data dan informasi dengan bantuan bermacammacam material yang terdapat di ruangan perpustakaan, seperti buku-buku, majalah, dokumen, catatan dan kisah-kisah sejarah dan lain-lainnya" (Mardalis, 2010).

Sesuai dengan judul yang peneliti angkat, maka penelitian ini menggunakan pendekatan kualitatif. Menurut Lexy. J. Meleong, metode kualitatif adalah sebagai prosedur penelitian yang menghasilkan data deskriptif berupa kata-kata tertulis atau lisan dari orangorang yang perilaku yang dapat diamati (Lexy.J.Meleong, 2002).

Sumber data yang akan peneliti gunakan adalah sumber data sekunder. "Sumber dari bahan bacaan disebut sumber sekunder" (Nasution, 2014). Data sekunder itu dapat mempunyai sumber primer atau sumber sekunder. Apabila tanggung jawab terhadap 
pengumpulan data dan penerbitannya berada dalam satu tangan, data sekunder itu dinamakan bersumber primer. Tetapi apabila tanggung jawab terhadap pengumpulan data itu berada dalam tangan yang berlainan dengan penerbitannya, sumber data itu dinamakan sumber sekunder.

\section{HASIL DAN PEMBAHASAN}

\section{A. Karakteristik Sistem Keuangan Islam}

Pertama, Nilai Ketuhanan. Menurut Yûsuf Qaradhawî, ekonomi Islam adalah ekonomi yang bercirikan ketuhanan. Sistem ini bertitik tolak dari Allah, bertujuan akhir kepada Allah. Penggunaan sarana dan fasilitas dari Allah ini dilakukan melalui hukum dan syari'at Allah SWT. Ketika seorang muslim menggunakan atau menikmati sesuatu di dunia ini, secara langsung ia telah melakukan ibadah kepada Allah, dan merupakan sebuah kewajiban baginya untuk mensyukuri segala nikmat-Nya yang telah diberikan kepadanya. Berdasarkan nilai filosofis ini, dalam ekonomi syariah muncul sebuah norma yang disebut norma al-istikhlâf. Adanya norma istikhlâf ini makin mengukuhkan norma ketuhanan dalam ekonomi syariah. Sebab, seorang muslim wajib percaya bahwa ia makhluk Allah, ia bekerja di bumi Allah, dengan kekuatan dari Allah, dan melalui sarana dan prasarana dari Allah. Seorang muslim bekerja sesuai dengan hukum kausalitas. Jika ia memperoleh harta, maka pada hakikatnya itu adalah harta Allah yang dititipkan kepadanya. Allah-lah yang menciptakan harta itu, dan Dia-lah pemilik sejati. Sementara itu, manusia hanya sebagai penjaga amanah yang telah diberikan kepadanya (Yusuf Qaradhawi, 1997).

Kedua, Nilai Dasar Kepemilikan (al-milkiyah). Konsep kepemilikan dalam Islam tidak sama dengan konsep kepemilikan dalam faham liberalisme seperti yang dikemukakan oleh Jhon Locke. Menurut Jhon Locke, setiap manusia adalah tuan serta penguasa penuh atas kepribadiannya, atas tubuhnya, dan atas tenaga kerja yang berasal dari tubuhnya. Artinya, kepemilikan yang ada pada diri seseorang adalah bersifat absolut. Oleh karena itu untuk apa dan bagaimana dia menggunakan harta tersebut adalah mutlak tergantung kepada kehendak dirinya. Hal ini tidak disetujui oleh Karl Marx. Marx berpendapat bahwa hal yang seperti itu adalah sangat berbahaya karena akan membawa kepada kehidupan yang eksploitatif dan penuh konflik (Anwar Abbas, 2004). Berbeda dengan dua pandangan tersebut di atas, Islam mengakui kepemilikan individual. Di samping itu, Islam pun mengakui akan adanya kepemilikan oleh masyarakat dan oleh negara. Akan tetapi, kepemilikan tersebut tidak bersifat absolut, tetapi bersifat relatif. Artinya, bahwa kepemilikan yang ada pada seseorang atau masyarakat atau negara tersebut bukanlah sepenuhnya milik dan hasil dari usaha mereka. Akan tetapi, semua itu merupakan amanat dan titipan dari Allah SWT. Oleh karena itu, seseorang tidak boleh menghambur-hamburkan hartanya, atau bahkan menuhankan hartanya. Jika demikian, berarti harta tersebut akan kehilangan fungsi sosial dan nilai manfaatnya (Anwar Abbas, 2004). Sehingga dalam ajaran Islam, kepemilikan manusia bukanlah penguasaan mutlak atas sumber-sumber ekonomi, karena pemilik mutlaknya adalah Allah, manusia hanya diberi amanat dan kemampuan untuk memanfaatkan sumber-sumber yang diamanatkan tersebut.

Ketiga, Keseimbangan (al-Muwâzanah). Sistem ekonomi kapitalis lebih mementingkan individu dibanding dengan masyarakat. Pada sistem ini seseorang merasakan harga diri dan eksistensinya. Orang diberi kesempatan untuk mengembangkan segala potensi dan kepribadiannya. Namun, akhirnya seseorang terkena penyakit egoistis, materialistis, pragmatis, dan rakus untuk memiliki segala sesuatu, dan orientasi kehidupannya merupakan profit motif. Dalam ajaran Islam, masalah keseimbangan mendapat penekanan dan perhatian secara khusus. Tidak hanya adanya keseimbangan antara kepentingan seseorang dengan kepentingan bersama, antara kepentingan dunia dan akhirat, antara kepentingan jasmani dan rohani, antara idealisme dan realita. Akan tetapi juga, keseimbangan antara modal dan aktifitas, antara produksi dan konsumsi, serta adanya sirkulasi kekayaan (Yusuf Qaradhawi, 
1995). Oleh karena itu, Islam mencegah dan melarang terjadinya akumulasi dan konsentrasi kekayaan hanya pada segelintir orang. (QS. 59 (al-Hasyr): 7) ....supaya harta itu jangan hanya beredar di antara orang-orang yang kaya saja di antara kamu... (QS. 59 (al-Hasyr): 7).

Sebaliknya jika terjadi kesenjangan kepemilikan yang tajam antar individu, berkaitan dengan pemenuhan kebutuhan-kebutuhannya, berarti telah terjadi praktek kezaliman. Untuk mengantisipasinya, Islam telah menawarkan solusi pemecahan melalui instrumen zakat, infaq dan sadaqah yang dapat menyentuh dan sekaligus mengentaskan kemiskinan. Keseimbangan merupakan nilai dasar yang mempengaruhi berbagai aspek tingkah laku seorang muslim. Nilai dasar keseimbangan ini harus dijaga sebaik-baiknya, bukan saja antara kepentingan dunia dengan kepentingan akhirat dalam ekonomi, tetapi juga keseimbangan antara hak dan kewajiban antara kepentingan individu, masyarakat dan lain sebagainya.

Keempat, Nilai Dasar Persaudaraan dan Kebersamaan (al-Ukhuwwâh wa alIsytirâkiyyah wa al-jamâ'ah). Pada paham sosialisme dan komunisme, persaudaraan dan kebersamaan merupakan nilai yang utama dan pertama. Untuk itu, agar nilai-nilai tersebut tidak rusak dan tidak terganggu maka kepemilikan individual yang menjadi penyebab terjadinya perselisihan dan persengketaan harus dihapuskan dan digantikan oleh negara. Negaralah yang mengatur produksi, konsumsi dan distribusi masyarakat. Dalam paham kapitalisme, hal ini tidaklah terlalu menjadi perhatian. Bagi mereka persaudaraan akan dapat terjadi secara otomatis diluar maksud para pelaku ekonomi itu sendiri, karena perekat persaudaraan, menurut paham ini adalah kepentingan.

Kedua paham di atas, berbeda dengan ajaran Islam. Dalam Islam, kebersamaan merupakan indikator atas keimanan seorang muslim. Nilai-nilai persaudaraan merupakan konsekuensi logis dari penunjukan manusia sebagai khalîfah fi al-ard, karena penunjukan tersebut bukan hanya ditujukan kepada orang-orang tertentu saja. Akan tetapi, ditujukan kepada setiap hamba-Nya yang beriman. Oleh sebab itu, perbedaan ras, etnik, dan bahasa bukanlah menjadi variabel pembeda di mata Allah SWT (Yusuf Qaradhawi, 1995).

Kelima, Nilai Dasar Kebebasan (al-Istiqlâliyyah). Dalam sistem ekonomi kapitalisme, setiap individu diberikan kebebasan yang seluas-luasnya untuk memanfaatkan atau tidak memanfaatkan harta yang dimilikinya. Juga untuk masuk atau tidak masuk ke dalam pasar, baik sebagai produsen, distributor, atau konsumen. Atau dengan perkataan lain, tidak ada yang bisa mengatasi kebebasan seseorang individu kecuali dirinya sendiri. Hal ini tidak dapat diterima oleh paham sosialis-komunis. Mereka melihat bahwa kebebasan seperti itu akan membawa kepada tindakan anarkis. Oleh sebab itu, kebebasan tersebut harus ditundukkan kepada kepentingan bersama (K. Bertans, 2002).

Keenam, Nilai Dasar Keadilan (al-'adâlah). Keadilan yaitu memberikan setiap hak kepada para pemiliknya masing-masing tanpa melebihkan dan mengurangi (Yusuf Qaradhawi, 1995). Persoalannya sekarang adalah siapakah yang berkompeten untuk menentukan keadilan tersebut? Pada sistem sosialisme dan komunisme, yang menentukan keadilan itu merupakan otoritas negara, sedang dalam sistem kapitalisme yang berkompeten adalah otoritas individu. Sementara itu, menurut persepsi Islam yang menetapkan keadilan itu merupakan otoritas dan kewenangan dari Allah SWT. Dalam masyarakat sosialisme dan komunisme, yang menjadikan kebersamaan dan kesamarataan sebagai nilai utama, maka faktor kebutuhan dijadikan dasar untuk menentukan sesuatu itu adil atau tidak. Menurut paham ini, suatu masyarakat baru dikatakan adil jika semua kebutuhan warganya telah terpenuhi, terutama kebutuhan sandang, pangan dan papan. Sebaliknya, jika tidak, maka telah terjadi praktek kedzaliman (K. Bertans, 2002).

Secara ekonomi, keadilan mesti ditegakkan dalam dua ranah sekaligus: Keadilan secara umum ( $\mathrm{Adl}$ 'am) bermakna perwujudan sistem dan struktur politik maupun ekonomi yang adil. Ranah ini merupakan tanggungjawab penguasa dan pemerintah. Keadilan secara 
khusus (Adl khas) bermakna pelaksanaan keadilan dalam kehidupan muamalah antar kaum muslim dan sesama manusia. Adl khas meliputi bidang yang luas seperti larangan melanggar hak orang lain. Islam tidak menghendaki adanya ketimpangan ekonomi antara satu orang dengan yang lainnya. Oleh karenanya salah satu keistimewaan penting dalam system ekonomi Islam adalah pengaturan perilaku rakyat dan pemerintahan yang meliputi dua dimensi materi dan spiritual sekaligus. Sebab dalam Islam, tujuan utama adalah mengantarkan manusia kepada kesempurnaan ruhani dan spiritual. Karena itu dalam sistem ekonomi Islam mekanisme yang dijalankan adalah untuk mendukung terwujudnya tujuan itu. Dua dimensi materi dan spiritual itu nampak jelas dalam ajaran Islam yang melarang monopoli, penimbunan harta (al-Ihtikar) dan perintah mengeluarkan zakat dan sedekah (M. Roem Syibly, 2015).

\section{Instrumen sistem keuangan Islam}

Tiap sistem ekonomi memiliki nilai instrumental tersendiri. Adapun nilai instrumental sistem ekonomi kapitalis adalah: persaingan sempurna, kebebasan keluar masuk pasar tanpa restriksi, serta informasi dan bentuk pasar yang atomistik monopolistik. Sedangkan nilai instrumental sistem ekonomi Marxis, antara lain adalah: adanya perencanaan ekonomi yang bersifat sentral dan mekanistik, serta pemilikan faktor-faktor produksi oleh kaum proletar secara kolektif.

Dalam sistem ekonomi syariah, nilai instrumental yang strategis yang mempengaruhi tingkah laku ekonomi seorang muslim, adalah:

Pertama; Zakat. Zakat adalah salah satu rukun Islam yang merupakan kewajiban agama yang dibebankan atas harta kekayaan seseorang menurut aturan tertentu dalam sistem ekonomi syariah (M. Daud Ali, 1998). Zakat merupakan sumber pendapatan negara. Di samping pajak, al-fay, ghanîmah dan harus dibagikan kepada yang berhak menerimanya.

Kedua; Pelarangan riba. Secara harfiah, arti riba adalah bertambah atau mengembang. Sedangkan menurut istilah, riba adalah tambahan dalam pembayaran hutang sebagai imbalan jangka waktu yang terpakai selama hutang belum dibayar (M. Daud Ali, 1998).

Ketiga; Kerjasama ekonomi. Kerjasama merupakan watak masyarakat ekonomi menurut ajaran Islam. Kerjasama harus tercermin dalam segala tingkat kegiatan ekonomi, produksi, distribusi baik barang maupun jasa. Bentuk-bentuk kerjasama tersebut diantaranya berupa muzâra'ah dan musâqah dalam bidang pertanian, mudhârabah dan musyârakah dalam perdagangan. Prinsip kerjasama tersebut dijunjung oleh ajaran Islam karena kerjasama tersebut akan dapat (M. Daud Ali, 1998): a). Menciptakan kerja produktif dalam kehidupan masyarakat sehari-hari. b). Meningkatkan kesejahteraan dan mencegah kesengsaraan masyarakat. c). Mencegah penindasan ekonomi dan distribusi kekayaan yang tidak merata. d). Melindungi kepentingan golongan ekonomi lemah.

Keempat, Jaminan sosial. Di dalam al-Quran banyak dijumpai ajaran yang menjamin tingkat dan kualitas hidup minimum bagi seluruh masyarakat.

Kelima, Pelarangan terhadap praktek-praktek usaha yang kotor. Ada beberapa praktek bisnis yang dilarang dalam Islam seperti pelarangan terhadap praktek penimbunan, takhfif (curang dalam timbangan), tidak jujur, tidak menghargai prestasi, proteksionisme, monopoli, spekulasi, pemaksaan dan lainlain. Hal ini dilarang karena bila ditolerir akan dapat merusak pasar sehingga kealamiahan pasar menjadi rusak dan terganggu.

Keenam, Peranan Negara. Untuk tegaknya tujuan dan nilai-nilai sistem ekonomi syariah diatas diperlukan power atau peranan negara terutama dalam aspek hukum, perencanaan dan pengawasan alokasi atau distribusi sumber daya dan dana, pemerataan pendapatan dan kekayaan serta pertumbuhan dan stabilitas ekonomi.

\section{Strategis Optimalisasi Sistem Keuangan Islam}


Menurut berbagai pemberitaan belakangan ini, banyak pihak berkeyakinan bahwa krisis keuangan global yang terjadi tidak berakibat buruk bagi industri perbankan syariah. Alasan yang mengemuka dari beberapa figur perbankan dan keuangan syariah dunia antara lain adalah karena keuangan syariah dilarang berhubungan dengan perdagangan utang (debt trading) dan perilaku spekulasi yang marak dilakukan oleh lembaga-lembaga keuangan Amerika dan Eropa. Menurut beberapa sumber lainnya, kalau pun ada pengaruhnya, dampaknya akan terbatas dan bersifat tidak langsung mengingat industri keuangan syariah merupakan bagian dari industri keuangan dunia. Namun dampak tersebut diyakini hanya berpengaruh pada laba perusahaan dan tidak menyentuh modal sebagaimana terjadi di beberapa lembaga keuangan

internasional.

Sebagaimana diketahui, krisis keuangan 2008 ini menurut banyak kalangan disebabkan oleh terjadinya kredit macet di sektor perumahan AS dan Eropa atau yang disebut subprime mortgages. Teorinya, suatu bank memberikan KPR kepada nasabahnya untuk jangka waktu tertentu. Kemudian, bersama-sama dengan KPR-KPR lainnya dipool kemudian disekuritisasi. Setelah itu dijual ke pasar dengan nama mortgages based securities (MBS). MBS ini kemudian masih diperdagangkan lagi dengan mempoolnya dengan MBS-MBS lain lalu disekuritisasi lagi. Padahal, banyak pemilik KPR tersebut sebenarnya tidak layak mendapatkan KPR karena ketidakmampuan mereka dalam membayar cicilan. Namun, faktor ini diabaikan karena mengharapkan bunga yang lebih besar dari nasabah yang mempunyai risiko lebih tinggi tersebut. Maka kemudian, terjadilah apa yang selama ini ditakutkan oleh praktisi lembaga keuangan yaitu ketidakmampuan membayar atau kredit macet yang meluas hingga berdampak pada runtuhnya beberapa lembaga keuangan di AS dan Eropa. Beberapa lembaga keuangan lainnya terpaksa dijual dan lainnya dinasionalisasikan. Dari sini dapat dilihat sisi buruk dari debt trading yang dalam keuangan syariah diistilahkan dengan bay' aldayn bi al-dayn.

Alasan kedua yang menghindarkan bank dan lembaga keuangan syariah dari krisis adalah haramnya perilaku spekulasi dalam transaksi keuangan syariah. Dalam keuangan syariah aksi spekulasi ini disebut maysir yang biasa dinisbahkan sebagai judi. Aksi margin trading dan short selling masih dilarang oleh para ulama fiqh karena masuk kategori maysir. Hal ini pula yang menjadi alasan belum dibolehkannya transaksi produk derivatif seperti forward, future, swaps dan options. Di samping itu, lembaga keuangan syariah juga dilarang terlibat dalam money laundering dan melakukan langkah-langkah formal dan profesional dalam melakukan penilaian terhadap proposal-proposal proyek agar terhindar dari risiko yang berlebihan (excessive risks). Tingkat kehati-hatian dalam keuangan dan perbankan syariah mencakup dua hal yaitu adanya prinsip kehati-hatian (prudent) dan kepatuhan terhadap syariah (sharia compliant).

Alasan lainnya adalah karena lembaga-lembaga keuangan syariah bukan menjadi investor utama dalam industri keuangan Barat sehingga tidak terkena dampak langsung krisis tersebut. Sebagaimana dijelaskan sebelumnya, banyak praktek-praktek transaksi keuangan yang tidak lolos verifikasi syariah seperti debt trading, margin trading, short selling, dan derivatif yang menjadi model transaksi belakang terjadinya krisis keuangan di negara-negara Barat. Dengan absennya "uang syariah" masuk ke lembaga-lembaga keuangan Barat melalui praktek-praktek keuangan di atas, maka aset keuangan syariah dapat terhindar dari efek langsung krisis global. Meskipun sedikit banyaknya keuangan syariah masih terkena dampak tidak langsung mengingat industri keuangan dunia semakin terhubung dan terintegrasi (connected and integrated) (Nuruddin Mhd Ali1, 2009).

Tujuan dan fungsi paling fundamental dari sistem keuangan Islam (Agustianto, 2002):

1. Kesejahteraan ekonomi yang menyeluruh berdasarkan full employment dan tingkat pertumbuhan ekonomi optimum. 
2. Keadilan sosio-ekonomi dengan pemerataan distribusi pendapatan dan kesejahteraan.

3. Stabilitas dalam nilai uang sehingga memungkinkan medium of change dapat dipergunakan sebagai satuan perhitungan, patokan yang adil dalam penangguhan pembayaran dan nilai tukar yang stabil.

4. Mobilitas dan investasi tabungan bagi pembangunan ekonomi dengan jaminan pengembalian yang adil dan prospektif.

5. Penagihan yang efektif dari semua jasa dan produk perbankan.

Untuk memberikan dampak yang lebih signifikan terhadap ekonomi, sistem keuangan Islam perlu memiliki porsi yang lebih signifikan terhadap total asset keuangan, yakni setidaknya 20 persen. Oleh karena itu, pemerintah, bank sentral, dan agen-agen ekonomi yang peduli pada sistem keuangan Islam perlu bekerja lebih keras. Terkait dengan itu, setidaknya ada lima langkah dalam mempercepat perkembangan sistem keuangan syariah, baik secara nasional maupun internasional.

Pertama, perlunya memperkuat sistem pengaturan dan pengawasan lembaga keuangan Islam. Tingkat pertumbuhan keuangan Islam sangatlah beragam di berbagai negara. Tingkat perkembangan ini memiliki korelasi yang positif terhadap tingkat pengaturan dan pengawasan. Sistem keuangan yang kurang baik di berbagai negara terkadang disebabkan tidak layaknya peraturan dan pengawasan yang ada, sehingga diperlukan kolaborasi dalam mengisi kesenjangan pengaturan yang ada.

Kedua, perlunya koordinasi dan kerjasama internasional. Berdasarkan kodratnya, sistem keuangan Islam lebih tahan dan lebih stabil dari guncangan keuangan. Namun demikian, pada kenyataannya, harus disadari bahwa operasional dari sistem keuangan Islam tidaklah terisolasi dari sistem keuangan konvensional. Dalam situasi demikian, diperlukan kerja sama dan koordinasi internasional. Saat ini, sudah terdapat beberapa lembaga internasional, seperti internasional Financial Services Board (IFSB) di Malaysia, International Islamic Financial Markets (IIFM), dan Accounting \& Auditing Organization for Islamic Financial Institutions (AAOIFI) di Bahrain. Peran dari institusi-institusi tersebut sebaiknya diperkuat dan ditingkatkan.

Ketiga, perlunya kolaborasi di tingkat pengawasan sistem keuangan Islam lintas negara. Saat ini, telah terlihat banyak lembaga keuangan Islam yang beroperasi secara global, namun memiliki kekurangan kolaborasi di dalam pengawasan lintas negara. Hampir seluruh kolaborasi pada sistem keuangan Islam fokus terhadap standar regulasi dan manajemen likuiditas.

Keempat, perlunya model bisnis sistem keuangan Islam khususnya di perbankan syariah, dengan memberikan penekanan pada bisnis di sektor rill ketimbang pasar keuangan. Selain lebih mempromosikan pertumbuhan yang berkesinambungan. Model seperti ini lebih mampu menahan tekanan krisis keuangan. Perkembangan keuangan ekonomi Islam di Indonesia sampai saat ini masih sejalan dengan model bisnis. Hal ini disebabkan adanya perkembangan produk sistem keuangan Islam yang didorong oleh pasar dalam memenuhi permintaan di sektor riil. Namun demikian, strategi ini bukan berarti melupakan upaya perkembangan produk-produk keuangan Islam di Indonesia yang terhitung masih agak tertinggal.

Kelima, perlunya penetapan acuan rate of return berdasarkan prinsip Islam yang sesungguhnya. Prinsip berbagi keuntungan dan kerugian merupakan semangat terciptanya sistem keuangan Islam. Namun demikian, sampat saat ini, lembaga keuangan Islam sepertinya cenderung mengacu pada rate of return sistem perbankan konvensional, yakni suku bunga. Perilaku seperti ini membawa risiko bagi reputasi lembaga keuangan Islam itu sendiri.

\section{PENUTUP}


Keuangan Islam adalah sebuah sistem yang bersumber dari Al-Quran dan Sunnah, serta dari penafsiran para ulama terhadap sumber-sumber wahyu tersebut. Dalam berbagai bentuknya, struktur keuangan Islam telah menjadi sebuah peradaban yang tidak berubah selama empat belas abad.

Karakteristik keuangan Islam adalah nilai ketuhanan, nilai dasar kepemilikan (almilkiyah), keseimbangan, Nilai Dasar Persaudaraan dan Kebersamaan, nilai dasar kebebasan dan Nilai Dasar Keadilan.

Instrument system keuangan Islam adalah zakat, larangan riba, kerjasama ekonomi, jaminan sosial, Pelarangan terhadap praktek-praktek usaha yang kotor serta adanya peranan negara dalam system ekonomi

Untuk memberikan dampak yang lebih signifikan terhadap ekonomi, sistem keuangan Islam perlu memiliki porsi yang lebih signifikan terhadap total asset keuangan, yakni setidaknya 20 persen. Oleh karena itu, pemerintah, bank sentral, dan agen-agen ekonomi yang peduli pada sistem keuangan Islam perlu bekerja lebih keras

\section{DAFTAR PUSTAKA}

Agustianto, Percikan Pemikiran Ekonomi Islam. Bandung: Citapustaka Media, 2002. Andri Soemitra, Bank Dan Lembaga Keuangan Shari'ah. Jakarta: Kencana, 2010.

Anwar Abbas, Dasar-Dasar Ekonomi Islam, Makalah: Disampaikan pada acara:Pelatihan Perbankan Syari'ah. Jakarta: UIN Syarif Hidayatullah, 2004.

Heri Sudarsono, Bank \& Lembaga Keuangan Syariah Deskripsi dan Ilustrasi, Edisi 2, Yogyakarta: Ekonisia, 2003.

K. Bertans, Pengantar Etika Bisnis, Yogyakarta: t.p, 2002.

M. Daud Ali, Sistem Ekonomi Islam Zakat dan Wakaf. Jakarta: UI Press, 1998

M. Umer Chapra, Islam Dan Tantangan Ekonomi: Islamisasi Ekonomi Kontemporer. Surabaya: Risalah Gusti, 1999

M. Umer Chapra, Sistem Moneter Islam, terj. Ikhwan Abidin B, Cet. Pertama. Jakarta: Gema Insani Press, 2000.

M. Roem Syibly, Keadilan Sosial Dalam Keuangan Syariah, Vol. XV, No. 1. Universitas Islam Indonesia, Yogyakarta: Millah, 2015.

Mervyn K. Lewis Dan Latifa M. Algoud, Perbankan Shari'ah: Prinsip, Praktik, Dan Konsep. Jakarta: Serambi, 2007.

Muhamad, Lembaga Keuangan Umat Kontemporer. UII Press Yogyakarta, 2000.

Nur Chamid, Tantangan Sistem Keuangan Islam Sebagai Alternative Sistem Keuangan Global, Vol. 6 No. 2 Jurnal al-'adl: Sekolah Tinggi Agama Islam Kediri, 2013.

Nuruddin Mhd Ali, Krisis Keuangan Global dan Upaya Aktualisasi Ekonomi Islam, Volume III, No. 1, STIE TAZKIA, La_Riba, 2009.

Nur Kholis, Potret Perkembangan dan Praktik Keuangan Islam di Dunia, Vol. XVII, no. 1 Millah: Jurnal Studi Agama: Universitas Islam Indonesia, 2017.

Novita Anjarsari, Perspektif Keuangan Islam Menghadapi krisis keuangan global:Tinjauan konseptual, Vol 2, No 1. Universitas Negeri Surabaya: Jurnal Akuntansi Unesa, 2013.

Qutb Ibrahim, Muhammad, Bagaimana Rasullulah Mengelola Ekonomi Keuangan Islam Dan System Administrasi. Gaung Perseda Press, 2007.

Said Sa'ad Marthon, Ekonomi Islam: Di Tengah Krisis Ekonomi Global. Jakarta: Zikrul Hakim, 2004.

Yusuf Qaradhawi, Norma dan Etika Ekonomi Islam. Jakarta: Gema Insani Press, 1997.

Yusuf Qaradhawi, Peran dan Nilai Moral dalam perekonomian. Jakarta: Rabbani Press, 1995. 
Zamir Iqbal dan Abbas Mirakhor, Pengantar Keuangan Islam: Teori dan Praktek, terj. Oleh A.K. Anwar. Jakarta: Prenada Media Group, 2008. 